\title{
Accumulative Mortgage System of Housing Provision for Military Personnel in Russia: Problems and Solutions
}

\author{
Vasilyeva L.P. \\ "Military University" of the Ministry of Defense of the \\ Russian Federation, \\ Moscow, Russia, \\ luda700619@mail.ru \\ Polyanskaya O.A. \\ Saint Petersburg State Forestry University \\ named after S.M. Kirov, \\ Saint-Petersburg, Russia, \\ Polyanskaya_78@mail.ru
}

\author{
Bespalova V.V. \\ Saint Petersburg State Forestry University \\ named after S.M. Kirov, \\ Saint-Petersburg, Russia, \\ weronika2002@yandex.ru \\ Okomina E.A. \\ Yaroslav the Wise Novgorod State University, \\ Veliky Novgorod, Russia, \\ Ekaterina.Okomina@novsu.ru
}

\begin{abstract}
In the development of the system of housing mortgage lending (HML), one of the main tasks of the state is to create a modern legislative framework and regulate the ongoing processes at the level of regulatory impact in order to reduce financial risks for its participants. The state acts as a regulator of mortgage relations, creates a legal basis for ensuring the most productive interaction between participants in the mortgage lending process, exerts a direct or indirect impact on them, and due to this, to attract new private investments into the housing sector, assists in the purchase of housing for various categories of the population. In the entire state housing policy, the formation of a modern HML system is one of the priority issues. Mortgage lending has a multifactorial impact on government development. At the same time, it is worth noting the positive impact of the development of the mortgage business on the real sector of the economy - industry, agriculture, construction, etc. World practice shows that the investment crisis can be overcome through the spread of mortgage lending, since this is an effective way to finance capital investments. This article provides a comprehensive analytical review of the application of economic and legal tools for managing the accumulative mortgage system for different categories of citizens. Based on the results of their comparison, shortcomings were identified in order to further determine the promising directions of its development.
\end{abstract}

Keywords-authorities, housing, mortgage, savings account, status of military personnel, targeted housing loans

\section{INTRODUCTION}

A mortgage in the general sense is a way to ensure that the borrower returns obligations to the lender through the collateralized real estate, while the lender can satisfy his monetary claims through the value of the collateral in the form of real estate. In a mortgage, the subject can be: apartments, multi-apartment and individual residential buildings, buildings, structures, land, and can also be in the form of other real estate.

According to A.A. Maksyutov, a mortgage is a kind of pledge, according to which the borrower has the right of ownership and the right to own the pledged object [1].

E.V. Koshel believes that a mortgage is a pledge of real estate including land in order to receive a loan in cash, i.e. mortgage or mortgage loan [2].

A.M. Tavasiev is of the opinion that a mortgage is a certain way to secure an obligation with immovable property, under the terms of such an agreement, if the pledgor does not fulfill his obligations, the pledgee can satisfy his claims through the sale of the pledged real estate. [3].

Presently, the current legislation does not contain a "direct" definition of the analyzed concept, while, an analysis of Article 334 of the Civil Code of the Russian Federation allows us to conclude that mortgage is a pledge of land, enterprises, buildings, structures, apartments and other real estate.

\section{PROBLEM STATEMENT}

The theoretical basis of the study were the works of such authors as A.A. Maksyutov, E.V. Koshel, A.M. Tavasiev, V.A. Moskvin, N.D. Eriashvili. and others, as well as regulatory legal acts of the Russian Federation and foreign countries.

Despite the large amount of information on this topic, there is currently no comprehensive economic and legal overview of 
the mortgage process. The statement of the problem consists in describing the mechanism for the implementation of the accumulative mortgage system of housing provision for military personnel in Russia in order to identify problems of an economic and legal nature and determine the prospects for its development.

\section{RESEARCH QUESTIONS}

The main research questions formulated in the work and acting as research objectives are the following.

- Conducting a comprehensive analytical review of theoretical aspects of economic and legal nature

- Comparing them with each other

- Identifying the problems of the accumulative mortgage system for providing housing for military personnel in Russia.

\section{PURPOSE OF THE STUdY}

The purpose of the study is to conduct a comprehensive analytical review of the economic and legal issues of the accumulative mortgage system for providing housing for military personnel, which will reveal its problems for the subsequent determination of development prospects.

\section{RESEARCH METHODS}

The study is based on traditional methods of information processing: content analysis of literary sources on the topic, logical analysis, systematization and prediction of comparison, and others.

\section{FINDINGS}

The issues of providing servicemen and their families with housing remain key in the social sphere of our state. Currently, the government believes that solving this problem is a priority. The right to have housing is part of the constitutional and legal status of a citizen, including military personnel, while this right is one of the most important socio-economic rights.

According to Art. 15 of the Federal Law No. 76 FL of May 27, 1998 "On the Status of Members of the Armed Forces" military servicemen undergoing military service, citizens who have already left military service and their family members must be provided with living quarters by the Ministry of Defense of the Russian Federation [4]

The President of the Russian Federation, in his instruction, approved that from January 1, 2005, a transition to the accumulative mortgage system (hereinafter AMS) should take place in order to provide servicemen with housing.

This form of housing provision has its own peculiarity, which consists in the fact that a serviceman participating in the AMS can use his right to be provided with housing through the implementation of savings formed on his personal savings account.

Let's carry out a comparative analysis of the provision of military personnel of the Russian Federation and Russia and the United States of America.

The housing system in these countries has both differences and some similarities. In America, it is based on the military retirement plan. For seniority, American military personnel have a high pension. Financial incentives for the US military include the following components: Social Security pension; military pension; personal contributions to retirement accounts in insurance companies, banks, investment funds [5].

The servicemen of this country are the most socially protected professional group of the population [6]

Regulatory sources governing the support system in the United States include: Section 10 "Armed Forces" of the US Code of Laws; "Law on payments to those dismissed from active military service"; "Military Pension Reform Act" and other [7]

Every year, the US Department of Defense monitors the standard of living of the population, on the basis of which it adjusts pension payments to military personnel. For this purpose, a Department of Defense pension fund was formed. [8].

As of fiscal 2010, US DoD pension fund assets were $\$ 1.46$ trillion. There are three possible payment plans for military retirees [9]:

- Final Pay - for those who entered military service before September 8, 1980. 50\% of the last official salary is taken as a basis, and for each additional year of service over 20 years, it increases by $2.5 \%$ of the official salary.

- High-3 - for those who entered the service from September 9, 1980 to August 1, 1986. 50\% of the average official salary for any three years of continuous service is taken as the basis, and for each year of service over 20 years, the pension increases by $2.5 \%$ of the average official salary

- CSB/REDUX - for those who entered military service after August 1, 1986. According to the regulations of the Ministry of Veterans, currently military pensioners are entitled to benefits: preferential medical care; life insurance; vocational rehabilitation programs; unemployment benefits; construction loans and others.

The legal basis for AMS in the Russian Federation is Federal Law No. 117-FL of August 20, 2004 "On the accumulative mortgage system of housing provision for military personnel", as well as other by-laws issued in the development of this federal law

The Russian Ministry of Defense acts as an authorized federal executive body that must ensure the functioning of the AMS. [10].

AMS participants exercise their right to housing through the following actions: savings are formed on the registered savings accounts of participants in order to provide housing, what they are subsequently used for; targeted housing loans are provided, that is, the money that the AMS participant receives, which is returnable gratuitous or repayable compensated; the participant's personal savings account also receives funds designed to supplement the savings for housing to the required estimated amount from the date of provision of these funds to the time of calendar calculation of 20 years of military service of the AMS participant that he could have accumulated during this time, not including income from the investment of these funds.

The sources of the accumulation of housing provision for 
the AMS participants are the following funds: funds from the federal budget in the form of accumulative contributions of participants, recorded in their individual accumulation accounts; income received as a result of investment of savings aimed at housing; other receipts permitted in the legislation of the Russian Federation.

Throughout the entire period of military service of the AMS participant, the accumulative contributions transferred from the federal budget quarterly are accounted for in the individual accumulative account, in accordance with the established procedure for the functioning of the accumulative mortgage system.

The Government of the Russian Federation, in Decree M655 of November 7, 2005, approved the Rules for maintaining registered savings accounts of AMS participants, according to which the procedure for organizing the work of the Ministry of Defense of the Russian Federation in terms of opening, maintaining and closing individual savings accounts of AMS participants is established.

Each AMS participant opens a registered individual savings account, as specified in the Rules of the Ministry of Defense of the Russian Federation.

The Federal State Institution "Federal Directorate of the Acumulative Mortgage System of Housing for Servicemen" maintains personal savings accounts, using paper and (or) electronic media, establishes the procedure for recording these data on the basis of Order of the Ministry of Defense of the Russian Federation No. 865 of December 17, 2013.

Accumulative contributions, which must be accounted for on the personal savings account of an AMS participant, begin to be calculated when there is a reason to include a specific participant in the register of the accumulating mortgage system. In this case, the date when he was actually included in the specified register, and when a registered savings account was opened for him, does not matter. The calculation of accumulative contributions is terminated when there are grounds for the AMS participant to be excluded from this register.

If, after the grounds appeared to exclude a serviceman from the corresponding register of AMS participants, contributions for housing were assessed, then they must be returned to the federal budget.

The Ministry of Defense of the Russian Federation transfers to asset management companies the savings for housing provision, transferring them to a separate bank account of the management companies, after they have been recorded on the registered savings accounts of AMS participants. The trust management agreements define the procedure and terms for these transfers. It is possible to transfer to trust management only that part of the housing supply that is accounted for in a registered savings account, except for the funds for targeted use sent to participants in accordance with the annual financial plan approved by the authorized federal body.

Also, other federal laws may regulate the area under study. For example, the Tax Code of the Russian Federation, clause 37 of Art. 217 exempts the income of individuals from taxation if it is received from the investment of funds of accumulative accounts of the AMS participants and is used to purchase (build) dwellings for the AMS participants. [11].
The Federal Law "On the Federal Budget" regulates the amount of funded contributions. In 2019, the amount of the accumulative contribution per one AMS participant is 280,009.70 rubles, according to 459-FL of November 29, 2018 "On the federal budget for 2019 and for the planning period of 2020 and 2021" To repay the mortgage loan in 2019, each AMS participant is sent by Federal State Treasury Institution Rosvoenipoteka a targeted housing loan in the amount of 23,334 rubles per month in 2019 . For 2019, the amount of the loan that can be obtained under this program is set at $2,417,977$ rubles. [12].

In the Legal Regulation of AMS, there are by-laws, normative legal acts that form a detailed level. This is the Decree of the President of the Russian Federation No. 449 of April 20, 2005 "Issues of the accumulative mortgage system of housing for military personnel", various Resolutions of the Government of the Russian Federation, defining the basis for the implementation of the accumulative mortgage system; individual organizational directions of this area are regulated by departmental legal acts. This level includes orders and instructions issued by the Ministry of Defense of the Russian Federation, the Federal Service for Financial Markets of the Russian Federation, various departments that have military service. (Federal Security Service, EMERCOM of Russia and Foreign Intelligence Service of Russia, Internal Troops of the Ministry of Internal Affairs of Russia, Service of Special Objects under the President of the Russian Federation).

Analysis of the practice of considering cases in courts allows us to draw conclusions about the negative aspects of the mortgage system [13] and in particular, the acumulative mortgage system of housing for military personnel.

For example, there is some inconsistency between the Federal Law "On the accumulative mortgage system of housing for military personnel" and the Federal Law "On the Status of Servicemen". It is also worth noting the impossibility of solving the problem of providing servicemen with housing through the specified form. "With annual government contributions of $\$$ 1,000 per year, as indicated in official sources, over 20 years the amount will be $\$ 20,000$. But what can be purchased for such an amount and in which region?

Thus, the difference in prices for residential premises located in different regions of Russia is not taken into account when forming housing savings and approving their size.[14]. In addition, the servicemen themselves are not interested in moving to a new duty station when they buy a home.

In the Federal Law "On the accumulative mortgage system of housing for military personnel" today there is no specific norm to protect the right of servicemen who are members of the AMS to receive their funds if one or another management company or several such companies have lost them.

In fact, these funds can be received by the military if the stock market and banks have a stable financial condition, that is, payments depend on how successful the activities of authorized companies selected by a special federal body will be. [15]. In other words, we must rely on the honesty and conscientiousness of the employees of these companies, so that they conduct effective activities, so that they always come across solvent counterpartiesto ensure the successful development of banking, insurance and stock systems, so that there is no default or other negative circumstances for all 20 
years, which a soldier serves while "fulfilling his right to housing". Otherwise, there may be a situation when a soldier and his family members, after 20 years of service, find out that they will not be able to buy an apartment that he planned to buy at the end of this period.

The issue of preserving housing rights by the family of a serviceman causes many legal disputes. For example, when one spouse is a member of the AMS, then the second spouse - a soldier - can not use a social employment contract for a family member - a member of the AMS and can no longer get a dwelling. Also, in judicial practice, there is a conclusion that a serviceman participating in the AMS cannot receive a living quarters, being a member of the soldier's family.

\section{RESULTS AND DISCUSSION}

1) Thus, we can summarize the identified problematic issues: the difference in the prices of residential premises located in different regions of Russia is not taken into account when forming housing savings and approving their size; there is no specific rule to protect the right of military personnel who are members of the AMS to receive their funds if one or another management company or several such companies have lost them; the list of assets where these funds are allowed to be invested does not meet the actual demand; the division of an apartment on a military mortgage acquired in marriage raises questions; there is a problem of unresolved issue of deletion from the register of AMS participants upon dismissal; the issue of using savings in case of early dismissal has not been resolved.

2) Consequently, it is relevant to improve the current legislation on the accumulative mortgage system of housing provision for military personnel in order to exclude the possibility of free interpretation of legislative norms and improve the quality of protection of the rights of military personnel.

\section{CONCLUSION}

Thus, AMS participants, through a military mortgage, can purchase an apartment or a separate house both in the primary and in the secondary real estate market.

The main legal act that regulates the exercise by servicemen of the right to housing and public relations in the field of AMS is Federal Law No. 117-FL of August 20, 2004 "On the accumulative mortgage system of housing for military personnel". It establishes organizational, legal, economic and social foundations in this area. This document defines the general provisions for the organization of the savings and mortgage system and housing provision for military personnel.
As part of the study, many problematic issues of the current legislation on the accumulative mortgage system of housing provision for military personnel were identified: the difference in prices of residential premises located in different regions of Russia is not taken into account when forming housing savings and approving their size; the lack of a specific rule, protection of the right of military personnel who are members of the AMS, to receive their funds if one or another management company or several such companies have lost them; the problem of the unresolved issue of deletion from the register of AMS participants upon dismissal; the issue of using savings in case of early dismissal has not been resolved

The solution of these problematic issues will help to increase the effectiveness of the implementation of the task of providing housing for military personnel.

\section{References}

(1) A.A. Maksyutov, Banking basics [Osnovy bankovskogo dela], Moscow: Berator-Press, 2016. (In Russ.)

(2) E.V. Koshel, The current state of the mortgage lending market and the prospects for its development [Sovremennoye sostoyaniye rynka ipotechnogo kreditovaniya i perspektivy yego razvitiya], Innovative science, 2017, vol. 4, pp. 116-1180. (In Russ.)

(3) A.M. Tavasiev, V.A. Moskvin, and N.D. Eriashvili, Banking. Short course [Bankovskoye delo. Kratkiy kurs], Moscow:: Unity-Dana, 2015. (In Russ.)

(4) Federal Law of 27.05.1998 N 76-FL (ed. From 02.12.2019) "On the Status of Servicemen".

(5) Sh. Captain, "The Water Soviet Naval officer", US Naval Gustitute Proceedings, 1999, vol. 2, p. 19

(6) S. Vado, "Hay que mejorar", Revista espanola de defensa, 1994, vol. 72, pp. $20-24$.

(7) S. Chapman, "The Hausing", Air forse magazine, 2013, vol. 6, pp. 36-41

(8) Stateside Legal, 2010. Retrieved from https://www.statesidelegal.org

(9) U.S. Social Security. Publication No. 05-10017, 2010. Retrieved from https://www.ssa.gov/pubs/EN-05-10017.pdf

(10) Federal Law of 20.08.2004 N 117-FL (as amended on 02.08.2019) "On the accumulative mortgage system of housing provision for military personnel".

(11) Tax Code of the Russian Federation (part one) of July 31, 1998 N 146 FL.

(12) Federal Law of November 29, 2018 459-FL "On the federal budget for 2019 and for the planning period of 2020 and 2021".

(13) J. Chen, and Y. Deng, "Commercial Mortgage Workout Strategy and Conditional Default Probability: Evidence from Special Serviced CMBS Loans", The Journal of Real Estate Finance and Economics, 2017, vol. 46(4), pp. 609-632.

(14) L. Guiso, P. Sapienza, L. Zingales, "The Determinants of Attitudes toward Strategic Default on Mortgages: Attitudes toward Strategic Default", Journal of Finance, 2015, vol. 68(4), pp. 1473-1515.

(15) E.M Ozhegov., and A.M. Poroshina, "The lagged structure of dynamic demand function for mortgage loans in Russia", EJournal of Corporate Finance, 2013, vol. 3(27), pp. 37-49. 